\title{
RAZLOZI, UČESTALOST I IZVORI INFORMIRANJA MLADIH O FINANCIJSKIM PITANJIMA
}

\author{
Ivan Balabanić \\ Fakultet hrvatskih studija, Sveučilište u Zagrebu, Zagreb, Hrvatska
}

\begin{abstract}
Sažetak
Financijska pismenost i financijska informiranost opisuju se kao znanje, vještine i ponašanje koji mogu ukloniti nepoželjne financijske rizike, kao i potaknuti poduzetničko ponašanje. Sa službenim takvim opismenjavanjem i obrazovanjem građana započelo su u svijetu početkom 2003. godine, a sustavnija istraživanja o toj tematici u Hrvatskoj su započela početkom 2015. S obzirom na to da su nositelji trendova mladi, ovo istraživanje usmjereno je na utvrđivanje informiranosti mladih o financijskim pitanjima, kao preduvjeta financijske pismenosti. U istraživanju smo se koristili mješovitom metodologijom koristeći Sequential Explanatory Design. Prvi dio istraživanja je proveden metodom ankete na uzorku od 1731 studenta, a drugi metodom fokus grupa koje su uključile 21 sudionika.
\end{abstract}

\section{Ključne riječi}

financijska pismenost; konzumacija medija; financijska informiranost; mješovita metodologija

\section{UVOD}

Usporedo s velikim rastom različitih proizvoda, roba i usluga sve je teže pri njihovoj kupnji i potrošnji donositi ispravne i racionalne odluke. Tako je raznolikost proizvoda i usluga tijesno povezana s upravljanjem osobnim financijama. Razvoj tehnologija, raznolikost proizvoda i usluga, kao i njihova dostupnost zasigurno donosi određene prednosti u svakodnevnom životu svih građana, no jednako tako donošenje neispravnih financijskih odluka pri kupovini takvih proizvoda $\mathrm{i}$ usluga može imati dalekosežne negativne posljedice na individualnoj kao i socijetalnoj razini (za gospodarstvo neke zemlje). Nesigurnosti i rizici kojima smo i financijski izloženi potaknuli su interes za sociološko proučavanje i istraživanje financijske pismenosti i neophodne informiranosti kupaca. Naime, za donošenje ispravnih financijskih odluka $\mathrm{i}$ racionalno upravljanje osobnim financijama o financijskim temama treba se dobro informirati te stečenim znanjem oblikovati ponašanje /1/. Dosadašnjim istraživanjima pokazalo se da nižu razinu financijske pismenosti pokazuju osobe mlađe od 19 godina, kao i starije od 70 godina /2/. Odnosno, da su mladi i osobe starije životne dobi najugroženije skupine kada je u pitanju financijska pismenost $\mathrm{i}$ informiranost.

Kako bismo utvrdili razloge, učestalost i izvore informiranja mladih o temama povezanim $\mathrm{s}$ financijama, proveli smo anketno istraživanje čiji su rezultati i interpretacija produbljeni metodom fokus grupa.

\section{FINANCIJSKA PISMENOST}

Tema financijske pismenosti relativno je novijeg datuma, a istaknula se kao prioritetna u vrijeme globalne financijske krize kad su zabilježeni veliki financijski gubitci kućanstava kao i povećanje blokiranih i zaduženih građana diljem svijeta /3/. Još uvijek ne postoji 
jednoznačna definicija financijske pismenosti. Financijska pismenost dio je onoga što se u literaturi definira kao financijska kultura /2/. Financijska kultura širi je pojam od financijske pismenosti, a osim potonje, uključuje financijske vještine i sposobnost za prepoznavanje i interpretaciju financijskih informacija, proizvoda $i$ usluga $u$ cilju racionalnog financijskog ponašanja /4/. Financijska pismenost kao dio financijske kulture potekla je iz bankarskih i financijskih institucija (poput Svjetske banke, Europske komisije i OECD-a) /5/. Naime, te institucije prve su započele sa službenim programima opismenjavanja i obrazovanja građana, a prvi put takva inicijativa započela je 2003. godine s ciljem podizanja financijske pismenosti, zaštite kućanstava s nižim primanjima, kao i osiguravanja dugoročne financijske stabilnosti ekonomskog i socijalnog sustava $/ 5 /$.

Financijsku pismenost možemo definirati kao razinu znanja, stavova i ponašanja prema osobnim, obiteljskim i poslovnim financijama. Financijska pismenost je „proces u kojem financijski potrošači i ulagači poboljšavaju razumijevanje financijskih proizvoda te putem informacija, uputa ili objektivnih savjeta razvijaju potrebne vještine i sigurnost kako bi postali svjesni financijskih rizika i prilika, kako bi mogli donositi utemeljene odluke, kako bi znali gdje se obratiti za pomoć te kako bi poduzimali druge učinkovite mjere za poboljšanje svoje financijske dobrobiti" /6/. Lusardi i Mitchell u svom su radu navele kako je financijska pismenost „pouzdani prediktor individualnog blagostanja, štednje, sudjelovanja na financijskom tržištu kao i planiranja mirovinskog osiguranja“/7/. Stoga, financijska pismenost nije samo zaštita i prevencija rizika, već sudjelovanje i stvaranje financijskih prilika uz uspješno ophođenje $s$ financijskim rizicima. Odnosno, financijska pismenost i informiranost pridonose pokretanju investicija, poduzetništva i gospodarstva u nekoj zemlji. Također, uočavamo da se financijska pismenost sastoji od više komponenti kao što su (1) znanje, (2) stavovi i (3) ponašanja. Dosadašnja istraživanja pokazala su kako većina svjetskog stanovništva nije upoznata $\mathrm{s}$ osnovnim financijskim konceptima koji su potrebni za sudjelovanje na financijskom tržištu te da navedene komponente (znanje, stavovi i ponašanja) nisu u visokoj korelaciji /6/, /7/.

\section{DOSADAŠNJA ISTRAŽIVANJA I ODREDNICE FINANCIJSKE PISMENOSTI}

Financijska pismenost općenito je na vrlo niskoj razini među građanima svih zemalja /7/. Prema podatcima istraživanja agencije Ipsos koje je provedeno 2015. godine prosječna ocjena hrvatskih građana kada je u pitanju financijsko znanje iznosilo je 4,2 od maksimalnih 7 bodova /2/. U odnosu na druge europske zemlje Hrvatske se našla na devetom mjestu, s ukupno $47 \%$ ispitanika koji imaju visok rezultat na skali financijskog znanja. Prvo mjesto zauzela je Mađarska, s ukupno 69\% ispitanika koji su na skali financijskog znanja postigli visok rezultat, a posljednje mjesto zauzela je Norveška, s ukupno $40 \%$ ispitanika. Kada je riječ o financijskom ponašanju, Hrvatska je zauzela deseto mjesto, s ukupno $38 \%$ ispitanika koji imaju visok rezultat na skali "financijskog ponašanja“. Prvo mjesto $u$ komponenti financijskog ponašanja zauzela je Njemačka (67\% ispitanika), dok je posljednje mjesto zauzela Estonija (27\%) /2/. Prva sustavnija istraživanja u Hrvatskoj koja su provedena u suradnji s OECD-om pokazala su neravnomjernu razinu financijske pismenosti među građanima koji dolaze iz različitih hrvatskih regija /6/. Najvišu razinu financijske pismenosti $u$ odnosu na komponentu financijskog znanja pokazali su građani iz sjeverozapadne Hrvatske. Znanje se mjerilo poznavanjem koncepata poput vrijednosti novca, inflacije, kamatnog računa, ulaganja i štednje. Istraživanje je također pokazalo kako su građani s područja sjeverozapadne i istočne Hrvatske usmjereniji prema planiranju budućnosti i odgovorniji prema financijama u odnosu na građane iz južne Hrvatske /6/.

No, osim regionalnih razlika na financijsku pismenost utječu i druge socio-demografske karakteristike, poput spola, dobi, razine obrazovanja, radnog statusa ili razine dohotka. Autorice Lusardi i Mitchell /1/ navode kako je slaba informiranost i financijska pismenost karakteristična za osobe nižeg dohotka i nižeg stupnja obrazovanja. Odnosno, u svom 
istraživanju otkrile su kako su viša razina obrazovanja i viša razina dohotka uglavnom popraćene višom razinom financijske pismenosti i informiranosti. Ti podatci slažu se i s podatcima o radnom statusu pojedinca. Podatci su pokazali da nezaposleni pojedinci jednako kao i oni s nižom razinom dohotka postižu slabije rezultate na skali financijske pismenosti od zaposlenih osoba i osoba s višom razinom dohotka /6/, /1/. Takvi navodi potvrđeni su i istraživanjem agencije Ipsos $u$ Hrvatskoj /2/.

U nekim istraživanjima moguće je pronaći tvrdnje kako su slabija informiranost i niža razina financijske pismenosti češće kod žena, dok $\mathrm{u}$ drugima nije zabilježena razlika u razini financijske pismenosti s obzirom na spol. Prema podatcima OECD-a pokazalo se da muškarci postižu bolje rezultate na skali financijske pismenosti od žena. Odnosno, ti podatci pokazali su da su osobe muškog spola sklonije riziku te da pokazuju veću razinu interesa i samopouzdanja kod donošenja financijskih odluka, dok su osobe ženskog spola češće koristile odgovor „ne znam“/8/. Prema istraživanju agencije Ipsos u Hrvatskoj se pokazalo postojanje statistički značajne razlike između muškaraca i žena $u$ odnosu na komponentu znanja, dok ta razlika nije uočena $\mathrm{u}$ odnosu na komponentu ponašanja /4/. Generalnog konsenzusa o učinku spola na financijsku pismenost i informiranost još uvijek nema. Autorice Lusardi i Mitchell navode kako nije jednostavno zaključiti postoje li jasne spolne razlike $\mathrm{u}$ odnosu na razinu financijske pismenosti te da su potrebna sustavnija istraživanja kako bi se donijeli ispravni zaključci /1/. S druge strane, većina istraživanja potvrdila je učinak varijable dobi na razinu financijske pismenosti i informiranosti /6/, /1/, /2/. Dosadašnjim istraživanjima pokazalo se da nižu razinu financijske pismenosti pokazuju osobe mlađe od 19 godina kao i osobe starije od 70 godina $/ \mathbf{2} /$.

Također, pojedini radovi problematizirali su obiteljsko okruženje i njegov utjecaj na financijsku pismenost. U Hrvatskoj, kao i drugim zapadnim zemljama, djeluju dva proturječna procesa. $S$ jedne strane dolazi do sve većih zahtjeva za obrazovanjem, profesionalnim i političkim angažmanom, dok se $s$ druge strane pojavljuju "postmodernizacijski“ oblici ponašanja „produžene mladosti“, a prepoznaju se u odbijanju društveno-političkog angažmana /9/. Većina mladih u Hrvatskoj još uvijek je materijalno ovisna i živi sa svojim roditeljima. Financijska sredstva mladih tako su uglavnom niska, mladi se ne bave planiranjem života $\mathrm{i}$ budućnosti te su zbog gubitka sigurnosti, zbog nezaposlenosti i nedovoljnih financijskih sredstava usmjereni prema pukom zadovoljavanju osnovnih potreba. TomićKoludrović u svom istraživanju, primjenom Lenzovog modela, utvrdila je kako su mladi s obzirom na način života uglavnom usmjereni prema obitelji i vršnjacima te postavljaju slične prioritete za svoj život, školovanje i rad /9/. Utjecaj obitelji na financijsko znanje, stavove i ponašanje odvija se kroz proces ekonomske socijalizacije /10/. Mi smo utvrdili da je financijska pismenost koncept koji je važan za izbjegavanje rizika, ali važna je i za pokretanje vlastitog posla te racionalno upravljanje osobnim financijama. Uloga obitelji vidljiva je kroz predispoziciju mladih za pokretanje vlastitog posla, odnosno s obzirom na njihov stav prema poduzetništvu. Dosadašnja istraživanja utvrdila su pozitivnu povezanost prethodnih obiteljskih poduzetničkih aktivnosti s budućnim poduzetničkim aktivnostima mlađih članova obitelji. Izloženost mladih poduzetništvu unutar obitelji stvara plodno tlo za samozapošljavanje, potiče kreativno poslovno razmišljanje, povećava samopouzdanje i otklanja strah od neuspjeha $/ \mathbf{1 1} /$, /12/. Prema tome, višu razinu financijske pismenosti kao i želje za pokretanjem vlastitog posla imat će oni pojedinci koji su odrastali u poduzetničkoj obitelji preuzimanjem obrazaca ponašanja od starijih članova obitelji.

\section{IZVORI INFORMIRANJA}

Živimo u umreženom svijetu u kojemu je pravovremena i valjana informacija od iznimne važnosti za svakog pojedinca i društvo. Autor Rubin /13/ slaže se da ljudi koriste medije da bi zadovoljili različite potrebe, od zabave, do educiranja i informiranja. Vrsta medija koju će pojedinac koristiti ovisi o dostupnosti tog 
medija kao i vrsti potrebe koja se želi zadovoljiti. Agencija Zenith /14/ već niz godina provodi istraživanje o medijskim navikama $u$ svijetu. Prema podacima iz 2015. godine, televizija je još uvijek najkorišteniji medij te je pojedinci koriste prosječno 177 minuta u jednom danu. Drugo mjesto zauzeo je Internet te ga građani koriste prosječno 119 minuta na dan. Na primjeru Srednje i Istočne Europe učestalost korištenja Interneta porasla je s 66,2 minute po danu 2010. godine na 136 minuta u 2018. godini. U odnosu na druge medije, jedini medij koji je zabilježio pad $\mathrm{u}$ odnosu na učestalost korištenja je tisak. Učestalost korištenja televizije porasla je s 212 minuta u 2010. godini na 219,5 minuta u 2018. godini, dok je učestalost korištenja radija porasla s 172,9 minuta u 2010. godini na 183,5 minuta u 2018. godini. Uprkos blagom rastu, najveću tendenciju rasta pokazao je Internet /14/. Istraživanje Ipsos agencije $u$ Hrvatskoj pokazalo je kako ispitanici najčešće koriste Internet $(91,6 \%)$, a prate ga televizija $(58,3 \%) \mathrm{i}$ radio $(45,9 \%) / \mathbf{1 5} /$. Zanimljivost $\mathrm{u}$ odnosu na korištenje Interneta je činjenica da nije uočena značajnija razlika u učestalosti korištenja Interneta s obzirom na dob /15/. Osim učestalosti korištenja pojedinog medija važno je spomenuti i vrstu sadržaja koja je prisutna u medijima te koji se najčešće prate. Analizom medijskog sadržaja Benković i Balabanić iz 2010. godine /16/ utvrdili su kako se medijski sadržaji najviše baziraju na zabavi $(22,3 \%)$. Vijesti iz politike zabilježene su na $9,5 \%$ priloga, a teme gospodarstva u ukupno 3,7\% analiziranih priloga. Kao najvažnije sadržaje u medijima ispitanici su istaknuli vijesti iz zemlje $(51,7 \%)$, lokalne vijesti $(40 \%)$ te zdravlje $(28,8 \%)$. Sadržaji vezani uz gospodarstvo zauzeli su osmo mjesto $(22,7 \%)$, dok su se teme vezane uz financije našle na četrnaestom mjestu (16,5\%). S obzirom na vrstu medija, vijesti s područja gospodarstva najučestalije se prate na Internetu $(55,3 \%)$ i televiziji $(47,3 \%)$. \$Također, teme o financijama najčešće se prate na Internetu $(62,7 \%)$, televiziji $(34,1 \%)$ i radiju $(17,7 \%) / \mathbf{1 6} /$. Csizarik - Koscir i Garai - Fodor /2/ proveli su istraživanje o otkrivanju motivacije pojedinaca da se samostalno educiraju i informiraju o financijama. Ispitanicima je bilo ponuđeno nekoliko tvrdnji te su za svaku tvrdnju morali procijeniti u kojoj mjeri se s njom slažu ili ne slažu. S tvrdnjom da je informiranje o financijama korisno jer može povećati financijske prilike $\mathrm{u}$ budućnosti složilo se $85,94 \%$ ispitanika. Osim toga, potvrdili su i tvrdnje kao „kroz edukacije i informiranje stvaramo veću svjesnost i odgovornost prema racionalnom financijskom ponašanju“, s kojom se složilo $83,5 \%$ ispitanika, dok se s tvrdnjom da „učenje o financijama korisno je jer se na taj način mogu izbjeći nepovratne financijske odluke" složilo $73,96 \%$ ispitanika /2/.

\section{CILJEVI ISTRAŽIVANJA}

Glavni cilj ovog istraživanja bio je definirati obrasce informiranja mladih o temama povezanim s financijama te dobivene podatke povezati $\mathrm{s}$ društvenom okolinom $\mathrm{u}$ kojoj $\mathrm{su}$ odrasli i u kojoj žive. Slijedom toga ciljevi ovog istraživanja su (1) ispitati u kojoj mjeri se mladi informiraju o financijama, (2) ispitati putem kojih medija se mladi najčešće informiraju o financijama, (3) ispitati učestalost informiranja o financijama s obzirom na imovinski status roditelja te (4) propitati ulogu obitelji $\mathrm{u}$ poticanju mladih na odgovorno ponašanje prema financijama i njihovih sklonosti poduzetništvu.

\section{METODOLOGIJA}

Kako bismo realizirali postavljene ciljeve, $\mathrm{u}$ istraživanju smo se koristili mješovitom metodologijom koristeći Sequential Explanatory Design /17/ na način da smo prvo proveli kvantitativno anketno istraživanje među studentskom populacijom, a nakon toga kvalitativno istraživanje korištenjem metode fokus grupa. U razdoblju od 1. travnja do 20. svibnja 2018. godine anketirani su studenti s 35 studija na sedam hrvatskih sveučilišta. Uzorkom su obuhvaćena sljedeća sveučilišta: Sveučilište u Zagrebu, Hrvatsko katoličko sveučilište, Sveučilište Sjever, Sveučilište J. J. Strossmayera u Osijeku, Sveučilište u Rijeci, Sveučilište u Zadru i Sveučilište u Splitu. Prije izbora jedinica uzorka okvir uzorkovanja podijeljen je u dva segmenta, u skladu s dvama velikim područjima znanosti kojima studiji pripadaju, tj. u prirodoslovno-tehničko- 
biomedicinsko-biotehničko i društvenohumanističko-umjetničko područje. Planirano je da udio sudionika iz navedenih znanstvenih područja u uzorku bude proporcionalan udjelu studenata koji to područje ima u studentskoj populaciji u Hrvatskoj. Primijenjen je dvoetapni neprobabilistički uzorak klastera. Prva etapa uzorkovanja bio je studij na pojedinom sveučilištu. Druga etapa izbora bili su studenti koji su prisustvovali nastavi predmeta na kojem je provedeno anketno istraživanje. Anketa je bila anonimna i provedena je metodom papirolovka. Ukupno je anketiran 1.731 student, a struktura je realiziranog uzorka prema spolu i području znanosti sljedeća:

\begin{tabular}{|l|c|c|}
\hline $\begin{array}{c}\text { Područje studijskog } \\
\text { smjera }\end{array}$ & $\mathrm{f}$ & $\%$ \\
\hline Prirodne znanosti & 63 & 3,6 \\
\hline Tehničke znanosti & 356 & 20,6 \\
\hline Biomedicina i zdravstvo & 121 & 7,0 \\
\hline Biotehničke znanosti & 67 & 3,9 \\
\hline Društvene znanosti & 926 & 53,5 \\
\hline Humanističke znanosti & 134 & 7,7 \\
\hline Umjetničko područje & 64 & 3,7 \\
\hline Total & 1731 & 100,0 \\
\hline
\end{tabular}

Tablica 1. Udio studenata uključenih istraživanja s obzirom na spol

\begin{tabular}{|c|c|c|c|}
\hline Spol & $\mathrm{f}$ & $\%$ & \\
\hline Muškarci & \multicolumn{2}{|c|}{600} & 34,7 \\
\hline Žene & \multicolumn{2}{|c|}{1131} & 65,3 \\
\hline Total & \multicolumn{2}{|c|}{1731} & 100,0 \\
\hline
\end{tabular}

Tablica 2. Udio studenata uključenih u istraživanje s obzirom na vrstu studija

Unutar završnog dijela istraživanja, krajem listopada 2018., provedene su dvije fokus grupe na uzorku studenata. Namjera organiziranja fokus grupa bila je dodatno produbiti razumijevanje o pojedinim tematskim cjelinama iz anketnog upitnika. Tako je glavni cilj kvalitativnog dijela istraživanja bio utvrditi i definirati obrasce kako obiteljsko okruženje u kojem pojedinac odrasta može oblikovati kasniju razinu financijske pismenosti i sklonost poduzetništvu. U istraživanju je sudjelovao ukupno 21 sudionik, od kojih 9 sudionica i 12 sudionika. Kako bi se detaljno istražili navedeni ciljevi, bilo je potrebno podijeliti sudionike na dvije fokus grupe prema određenim kriterijima. Stoga su sudionici bili podijelili prema osnovnom kriteriju materijalnih primanja vlastite obitelji u kojoj su odrastali ili još uvijek žive . Navedeni kriterij bitan je zbog usporedbe percepcije i sklonosti poduzetništvu onih ispitanika koji dolaze iz obitelji $\mathrm{s}$ iznadprosječnim te prosječnim i ispodprosječnim primanjima. Nadalje, svi sudionici bili su studenti različitih studija i razina studija, što je također bilo bitno zbog heterogenosti interesa i polja koja studiraju.

\section{INTERPRETACIJA REZULTATA}

Prvi cilj istraživanja bio je utvrditi koliko se često mladi informiraju o financijskim temama. Dobiveni podaci (Tablica 3.) pokazuju da se mladi vrlo rijetko informiraju o financijskim temama. Naime, čak $49 \%$ studenata uključenih $\mathrm{u}$ istraživanje navelo je kako se rijetko informira o temama s područja financija, a njih $23 \%$ ne informira se gotovo nikad. Tek $3 \%$ studenata o temama povezanih s financijama se dnevno informira, $7 \%$ nekoliko puta tjedno, te $18 \%$ studenata uključenih $\mathrm{u}$ istraživanje informira se nekoliko puta mjesečno. $S$ obzirom na spomenute nesigurnosti i rizike koji su povezani s financijama te utvrđenom niskom financijskom informiranosti /3/, /16/ opravdano se možemo pitati koliko razinu financijske pismenosti mladi kao budući akteri na financijskom tržištu i tržištu rada imaju te u kojoj mjeri je potrebno naglašavati važnost financijske pismenosti kao i ulogu relevantnih društvenih aktera poput političara, medija i institucije obrazovanja. S obzirom da se financijska tehnologija konstantno razvija te da se na tržištu pojavljuju novi proizvodi i usluge potrebno je raditi na većoj financijskoj pismenosti i financijskoj informiranosti posebice onih skupina koje su u tom aspektu najugroženije, kako osobe starije životne dobi, tako i mladi čija se informiranost $\mathrm{u}$ ovom radu utvrđuje. Ako se mladi rijetko ili gotovo nikada 
ne informiraju o temama s područja financija, ne možemo tvrditi da postoji visoka razina financijske pismenosti jer je informiranost preduvjet za razumijevanje financijskih proizvoda i koncepata, te preduvjet za razvijanje potrebnih vještina i sigurnosti da bi mladi $u$ budućnosti donosili utemeljene i racionalne financijske odluke i time poboljšali svoju financijsku dobrobit /6/. Razlog niskoj učestalosti informiranja o temama s područja financija može biti i dostupnost takvih sadržaja na medijima. Kako su dosadašnja istraživanja pokazala vijesti s područja financija u manjoj su mjeri zastupljene $u$ odnosu na druge, poput zabave ili vijesti iz zemlje /16/. S druge strane, teme iz gospodarstva ne mogu se u potpunosti poistovjetiti $\mathrm{s}$ financijskim temama stoga $\mathrm{i}$ pokrivenost gospodarstva kroz medijske sadržaje ne garantira mogućnost informiranja o najvažnijim temama povezanim s osobnim financijama

Tablica 3. Učestalost informiranja mladih o temama s područja financija

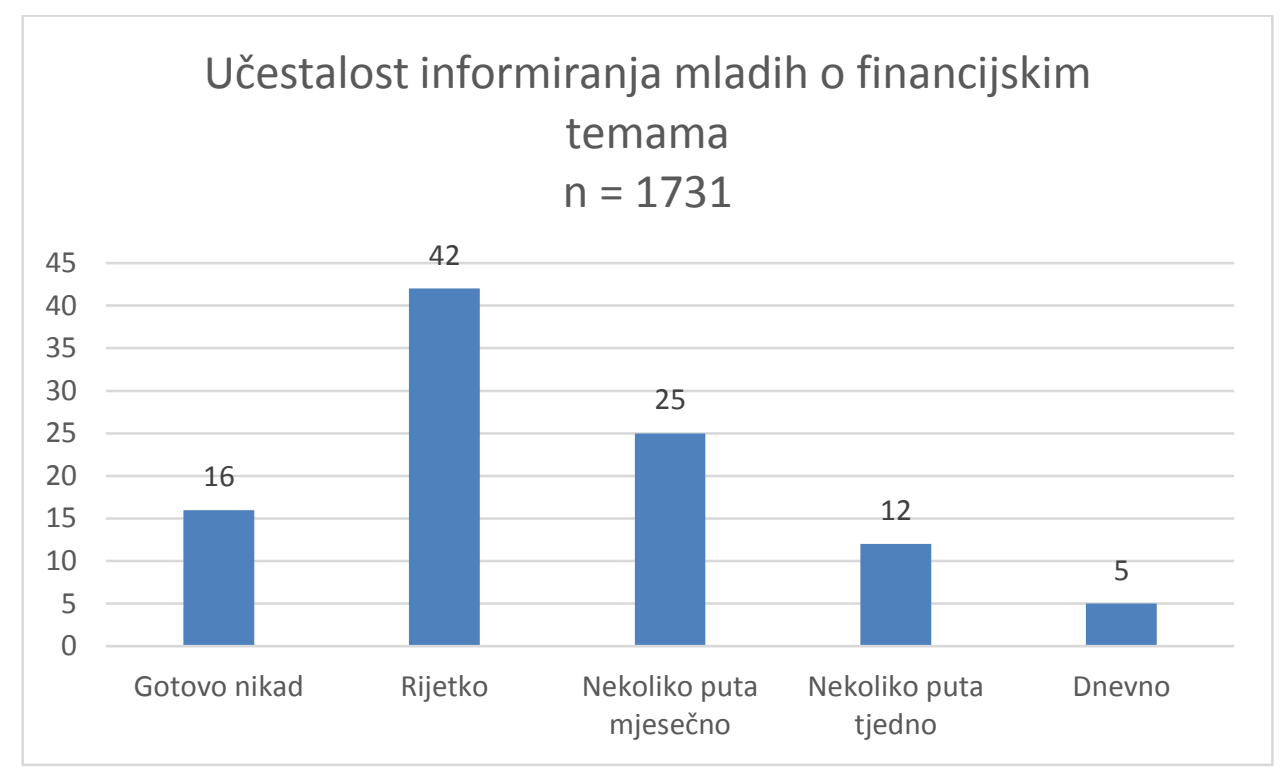

Tablica 4. Učestalost informiranja o temama s područja financija s obzirom na spol 


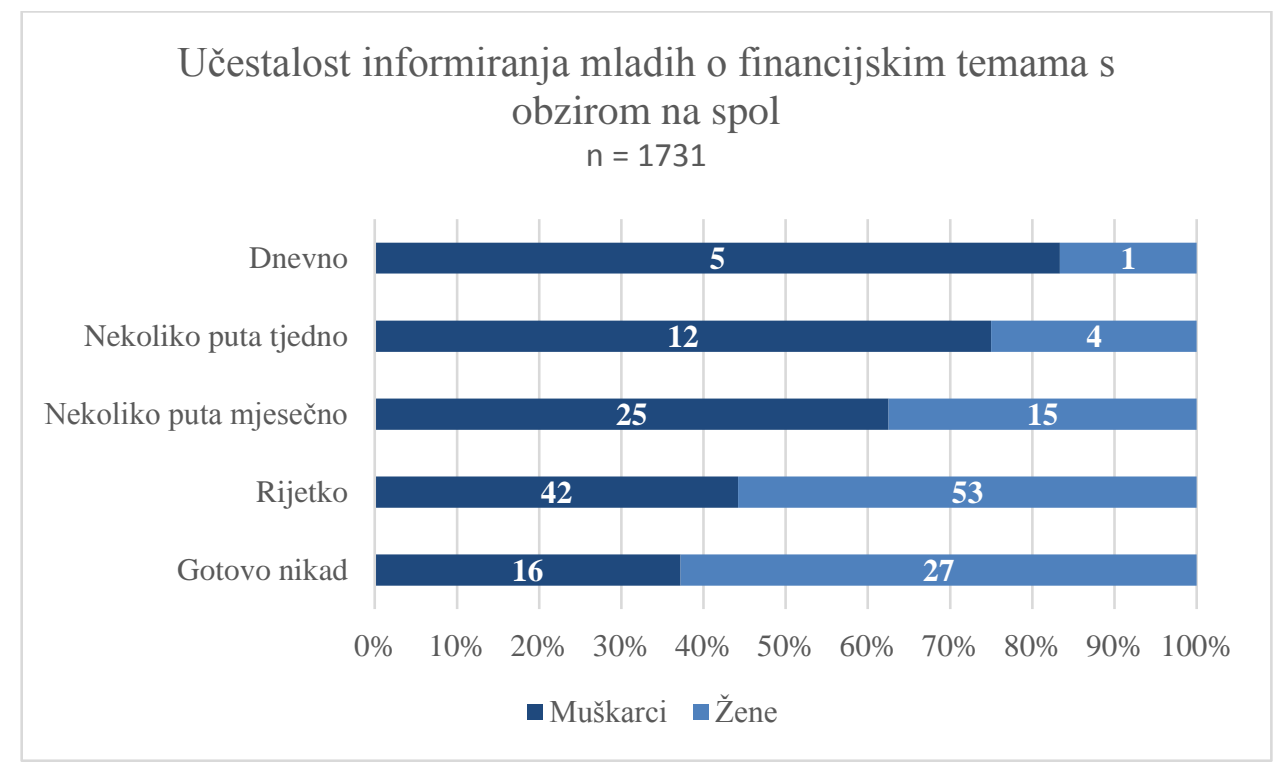

S obzirom pak na izvor informiranja ili na vrstu medija, studenti se najčešće informiraju putem Interneta, portala i društvenih mreža $(74,6 \%)$. Drugo mjesto zauzela je televizija s $27,2 \%$ ispitanika koji se putem tog medija informiraju. Zatim slijede tiskani mediji (dnevne novine i časopisi) s $12,2 \%$, a radio se našao na zadnjem mjestu s ukupno 1,9\% ispitanika koji se informiraju putem ovog medija. S obzirom na spol (Tablica 5.) ispitanici muškog spola najčešće se informiraju o temama s područja financija putem Interneta, na portalima i putem društvenih mreža (62\%), a osobe ženskog spola najčešće se informiraju putem tiskanih medija, dnevnih novina i časopisa (43\%). Osim razlike $\mathrm{u}$ već spomenutoj učestalosti, učestalost korištenja različitih vrsta medija kada su u pitanju teme povezane s financijama, može biti povezana s percepcijom korisnosti određenog medija i potrebe koju treba zadovoljiti. Osobe muškog spola vjerojatno smatraju kako će putem Interneta, portala i društvenih mreža saznati dovoljno potrebnih informacija o financijskim temama, dok žene veće povjerenje imaju u tiskane medije. No, unatoč tim razlikama Internet je i u ovom slučaju ipak sredstvo koje se najučestalije koristi, što je $\mathrm{u}$ skladu $s$ dosadašnjim istraživanjima o medijskim navikama /15/. Osim prema spolu, putem Interneta se najčešće informiraju studenti s područja društveno-humanističkih znanosti $(62 \%)$, kao i slučaju informiranja putem tiskanih medija, dnevnih novina i časopisa (64\%), što nije iznenađujuće s obzirom da se studenti s područja društvenohumanističkih znanosti češće tijekom studija susreću s političkim, ekonomskim i drugim društvenim temama.

Tablica 5. Učestalost informiranja mladih s obzirom na vrstu medija i spol 


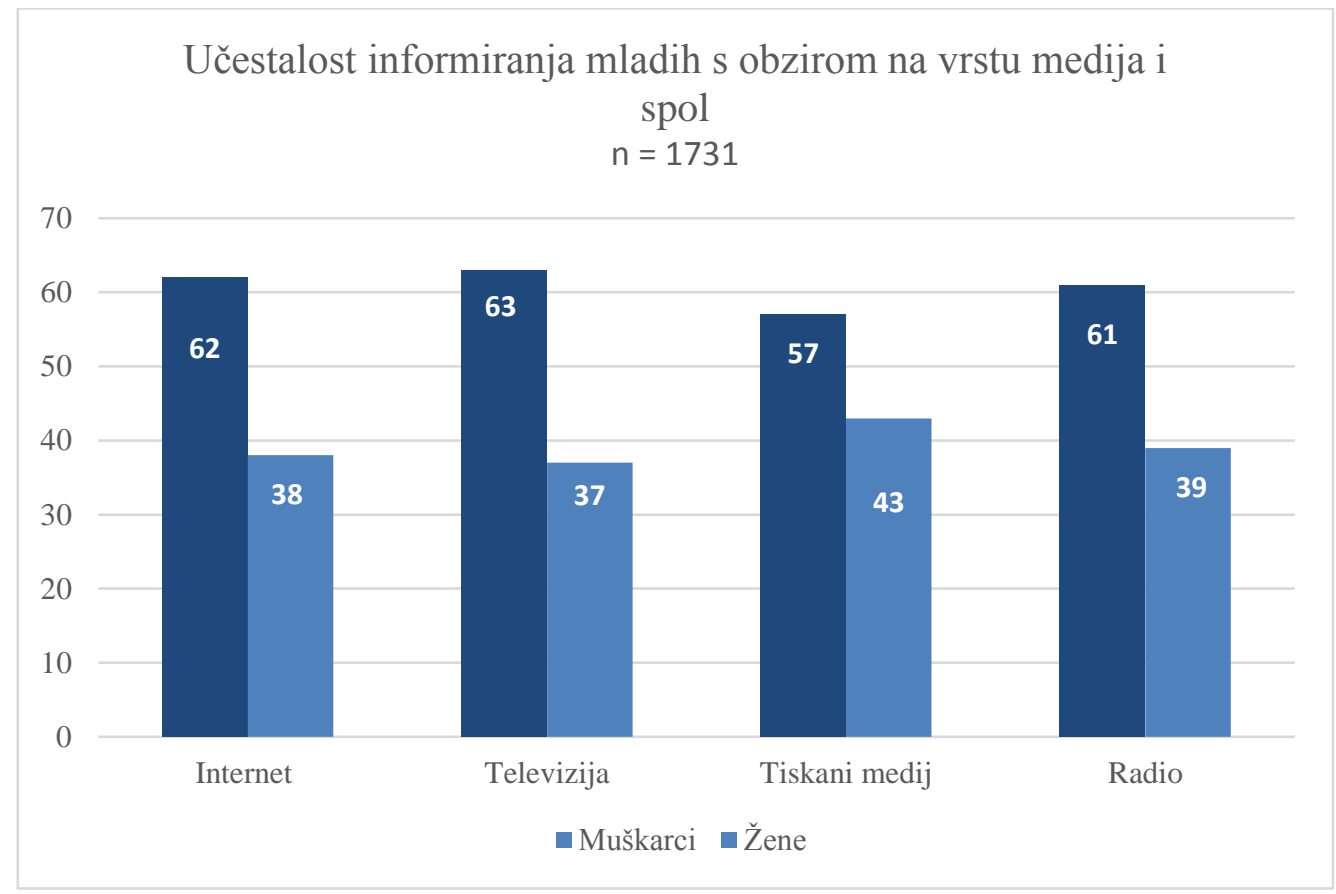

U sklopu drugog dijela istraživanja provedene su fokus grupe među studentima. Fokus grupama željelo se produbiti razumijevanje o pojedinim tematskim cjelinama, a među njima ispitati također na koji način obitelj oblikuje preferencije prema poduzetništvu te koliko često članovi obitelji razgovaraju o temama povezanim s financijama. Sudionici su bili podijeljeni $u$ dvije grupe prema kriteriju imovinskog statusa. Sudionici prve grupe bili su oni s iznad prosječnim imovinskim statusom roditelja, dok su u drugoj grupi bili sudionici s ispod prosječnim imovinskim statusom roditelja. Kada su upitani o tome koliko se često unutar njihove obitelji razgovora o financijama, u slučaju i jedne $\mathrm{i}$ druge grupe uočen je nedostatak izravnog razgovora o financijskim temama unutar obitelji. Razlika u slučaju prve i druge grupe je $\mathrm{u}$ tome što se $\mathrm{u}$ drugoj grupi naglašavala važnost štednje kao važnog dijela osobnih financija koje se tiče ne samo pojedinih članova već cijele obitelji, dok u prvoj grupi taj slučaj nije zabilježen. Tako je jedan od sudionika prve grupe istaknuo:

"Ne znam, mi ne pričamo tol'ko o financijama, ali ako je, ne znam, priča o stipendiji, onda se moraju spomenuti financije, onda kako, što, pa porezna olakšica, pa jesi nisi, pa šta moraš, moraš otvorit' račun, pa šta ti treba. Ako je neki baš problem, onda se uhvatimo toga" $(L)$.
Sudionici prve grupe uglavnom su navodili kako se o financijskim temama u obitelji nije govorilo ciljano i izravno, već unutar neke druge tematike, kao što su politička ili gospodarska zbivanja u zemlji. Ipak, ako se o tome razgovaralo, uglavnom je bila riječ o osobnim financijama i temama koje su povezane $s$ troškovima kućanstva i budućim obiteljskim investicijama. S druge strane, razgovori u prvoj grupi su ukazali na rijetko spominjanje štednje unutar obitelji.. Kad je riječ o štednji, sudionici prve grupe su se složili kako je bolja odluka potrošiti novac trenutno, nego dugoročno štedjeti. Kod sudionika druge grupe uočeni su suprotni trendovi. Naime, sudionici druge grupe istaknuli su da s roditeljima razgovaraju o osobnim financijama. U razgovoru o osobnim financijama uglavnom su se spominjali rashodi kućanstva, a često se naglašavala i važnost štednje. Tako je sudionik iz druge grupe istaknuo:

"Onda kako je došla kriza i sestra je upisala faks, sve je to onda stalo. Onda je dosta često znalo biti govora: „pa znaš moraš malo tu uštedjeti, pa malo ovamo uštediti“. Ali da, bilo je govora dosta često, moramo malo tu uštedjeti. Što se tiče neke štednje, razgovarala jesam sa svojima uvijek, ali mislim da je, rekla bi da su kamatne stope kod nas toliko, čak mizerne, da se to jednostavno ne isplati“. (I). 
Važnost štednje kod sudionika iz druge grupe istaknula se kao mogućnost financiranja vlastitih potreba u budućnosti. Ovaj nalaz upućuje na razlike između prve i druge grupe sudionika. Razgovori o važnosti štednje krenuli su s nastupom financijske krize, čime su bile smanjene platne mogućnosti građana. Danas je to ostao dominantan obrazac ponašanja koji se prenosio s roditelja na njihovu djecu, dok sudionici prve grupe ne naglašavaju važnost štednje ili takvo djelovanje ne prakticiraju dugoročno.

Osim razgovora o financijskim temama, kroz fokus grupe propitali smo i učestalost razgovora o poduzetništvu. Sudionici prve grupe pokazali su pozitivno mišljenje o poduzetništvu, te su češće navodili kako ih roditelji potiču da i sami krenu u ostvarenje vlastitih poslovnih ideja uz uvjet završetka visokoškolskog obrazovanja. Općenito, prva grupa sudionika iskazala je otvoreniji stav prema razmišljanju o samostalnim poduzetničkim pokušajima. Tako je jedna sudionica iz prve grupe istaknula:

„Pa da, slična je situacija kod mene. Poticanje da se uključim u što mogu i gdje mogu. Znali bi da uvijek mogu nešto bolje, recimo da budem profesorica $u$ školi, ajde probaj nešto više." (B).

Kad je riječ o karijeri ili poticanju pronalaska stabilnog posla, sudionici dviju grupa se dominantno razlikuju po svojim kazivanjima. Sudionici prve grupe složili su se kako ih roditelji potiču, počevši od samog procesa studiranja na korištenje svih prilika koje se nude - od projekata, do putovanja. To je razlog zbog kojeg planiraju nastaviti $\mathrm{s}$ takvim aktivnostima i izgradnjom dinamične karijere. U drugoj grupi, većina sudionika istaknula je negativno mišljenje prema poduzetništvu. Ono što se posebno negativno naglašavalo bila su: prevelika osobna odgovornost, pitanje financijske održivosti te problem birokracije u Hrvatskoj. Uz negativnu percepciju o poduzetništvu istovremeno se može uočiti obeshrabrenost mladih spram vlastite poduzetničke aktivnosti i tendencija traženju sigurnog i stabilnog posla, čime se posebno razlikuju od percepcija u prvoj grupi. Tako je jedna sudionica iz druge grupe istaknula:
„Veliki je zapravo jako postotak tipa start-up-a koji $u$ proih 2 godine propadnu. Znači jako puno se toga otvara, al' zapravo jako malo toga zaživi. Tako da složila bih se da je zapravo vrlo teško to održat' na nekoj dugoročnoj razini“. (I).

Sukladno tome, uz negativnu percepciju o poduzetništvu istovremeno se može uočiti obeshrabrenost mladih $\mathrm{u}$ pogledu vlastite poduzetničke aktivnosti i tendencija u traženju sigurnog i stabilnog posla, što se razlikuje od rezultata prve grupe sudionika. $S$ obzirom na dosadašnja istraživanja /11/, /12/ koja su utvrdila utjecaj obiteljske pozadine na poduzetničke aktivnosti i interes za financijama na mlađe članove obitelji, rezultati fokus grupa govore nam o razlikama između prve i druge grupe sudionika, koji se razlikuju prema imovinskom statusu njihovih roditelja. Oni sudionici koji dolaze iz materijalno sigurnijih uvjeta potvrdili su pozitivan stav prema poduzetništvu te tendenciju prema stvaranju dinamične karijere, dok se u drugoj grupi istaknula važnost štednje te negativan stav prema poduzetništvu i tendencija prema pronalasku stabilnog i sigurnog posla. No, ono što je također zanimljivo su iskazi druge grupe čiji roditelji imaju ispod prosječan imovinski status kako najviše strahuju od velike odgovornosti posebice $\mathrm{u}$ vrijeme ekonomske nesigurnosti, nezaposlenosti i manjka financijskih sredstava zbog čega su mladi više usmjereni prema traženju sigurnog i stabilnog posla bez većih investiranja /9/. Iako, ovim istraživanjem nije utvrđena potrebita financijska informiranost kao i obiteljski razgovori o financijskim temama, možemo se složiti s tvrdnjom kako će veći interes za financijska pitanja i poduzetništvo imati oni pojedinci koji su odrasli u poduzetničkoj obitelji i čiji roditelji takvo ponašanje potiču.

\section{ZAKLJUČAK}

Cilj ovog istraživanja bio je utvrditi učestalost informiranja mladih o financijskim temama, kao i utjecaj obitelji na njihov interes za takve teme i poduzetništvo. Mladi uključeni $u$ istraživanje pokazali su kako se tek rijetko ili gotov nikad ne informiraju o temama $s$ područja financija. Usprkos niskoj razini informiranosti o temama s područja financija, 
ispitanici muškog spola pokazali su veću učestalost informiranja o tematici vezanoj za financije, ali to ne znači da su studenti financijski pismeniji nego studentice $u$ Hrvatskoj, nego samo da iz više zanima takav medijski sadržaj. Ispitanici s obzirom na spol razlikuju se i u vrsti medija koji najčešće koriste za informiranje o temama s područja financija. Ispitanici muškog spola češće se informiraju putem Interneta, dok se osobe ženskog spola o financijskim temama češće informiraju putem tiskanih medija, dnevnih novina i časopisa. Zanimljivost ovog istraživanja, koje može biti i smjernica budućim istraživanjima jest dobivani rezultata da se osobe $\mathrm{s}$ ispod prosječnim imovinskim statusom rjeđe informiraju o temama s područja financija u odnosu na one s prosječnim ili iznad prosječnim imovinskim statusom. Obitelj također djeluje kao važan faktor budućeg poslovnog, poduzetničkog i financijskog ponašanja. Naime, oni sudionici koji dolaze iz obitelji s višim imovinskim statusom pokazali su veći interes prema stvaranju dinamične karijere i pokretanju vlastitog posla, dok sudionici koji dolaze iz obitelji $\mathrm{s}$ ispod prosječnim imovinskim statusom ipak osjećaju strah od pokretanja vlastitog posla, te se češće odlučuju na traženje sigurnog i stabilnog posla. Osim također kao smjernica budućim istraživanjima, ovaj podatak trebao bi potaknuti veći angažman relevantnih društvenih aktera $u$ podizanju svijesti o važnosti financijske pismenosti kako bi se izbjegli negativni financijski ishodi, koji djeluju ne samo na pojedinca i obitelj već i na gospodarstvo neke zemlje.

\section{Bilješke}

/1/ Lusardi, A., Olivia S.M. (2011). “Financial Literacy around the World: An Overview", Journal of Pension Economics and Finance, vol. 10, br. 4, str. 497-508.

/2/ Ipsos Public Affairs. (2015). “Mjerenje financijske pismenosti i financijske uključenosti $u$ Hrvatskoj", preuzeto s https://www.hanfa.hr/getfile.ashx/?fileId=43343

/3/ Anđelinović, M., Pavković, A., Mišević, D. (2016). “Mjerenje financijske pismenosti studenata
Sveučilišta u Zagrebu", EFZG serija članaka u nastajanju, vol. 16, br. 10, str. 2 - 20.

/4/ Csiszarik-Kocsir, A., Garai-Fodor, M. (2018). "Why is it important to learn finances? Results based on the opinion of $\mathrm{Z}$ generation", Poslovna izvrsnost Zagreb, vol. 12, br.2 str. 41-58.

/5/ Balen, M. (2017). "Financijska pismenost i obrazovanje u Hrvatskoj", Političke analize.

/6/ Vehovec, M., Rajh, E., Škreblin Kirbiš, I. (2015). "Financijska pismenost građana u Hrvatskoj", Privredna kretanja i ekonomska politika, vol 24., br. 1, str. 53-76

/7/ Vehovec, M. (2011). “Financijska i mirovinska pismenost: međunarodna iskustva i prijedlozi za Hrvatsku", Privredna kretanja i ekonomska politika, vol. 21, br. 29, str. 65-85

/8/ Škreblin Kirbiš, I., Vehovec, M., Galić, Z. (2017) "Relationship between financial satisfaction and financial litercy: exploring gender differences", Društvena istraživanja: časopis za opća društvena pitanja, vol 26., br. 2, str. 165-185

/9/ Ilišin, V. (2015). "Paradoksi demokratskog potencijala suvremene generacije mladih", Institut za društvena istraživanja: Zagreb.

/10/ Visković, I. (2018). “Odgojno obrazovni aspekti ekonomske funkcije obitelji”, Napredak, vol. 7., br. 3, str. 1 - 11

/11/ Schenkel, M. T., Brazeal, D. V., Azriel, J. A. (2013). "Pathways in the development of entrepreneurial intent: exploring the roles of prior experience, sex and family business", Journal of Business and Entrepreneurship, vol. 24., br. 2, str. 47-68.

/12/ Tarling, C., Jones, P., Murphy, L. (2016). "Influence of early exposure to family business experience on developing entrepreneurs", Education+ Training, vol. 58, br. 7/8., str. 733-750

/13/ Rubin, A.M. (2002). "The Uses-andGratifications Perspective of Media Effects", Media Effects: Advances in Theory and Research. Lawrence Eribaum Associates: New York

/14/ Zenith - The Roi Agency. (2016). "Media consupmtion forecasts", preuzeto s https://communicateonline.me/lvt/wpcontent/uploads/2016/06/Media-ConsumptionForecasts-2016.pdf

/15/ Ipsos Connect. (2019). “Medijske navike u Republici Hrvatskoj", preuzeto s https://showcase.24sata.hr/2019_hosted_creative s/medijske-navike-hr-2019.pdf

/16/ Benković, V., Balabanić, I. (2010). “Analiza sadržaja najposjećenijih hrvatskih intenetskih portala", Medijska istraživanja: znanstvenostručni časopis za novinarstvo i medije, vol. 16., br. 2, str. 43-57.

/17/ Creswell, J.W. (2014). "Research Design: Qualitative, Quantitative, and Mixed 
Methods Approaches (3 $3^{\text {rd }}$ Edition), Sage

Publications.

\title{
REASONS, FREQUENCY AND SOURCES OF INFORMING YOUNG PEOPLE ON FINANCIAL ISSUES
}

\author{
Ivan Balabanić \\ Faculty of Croatian Studies, University of Zagreb, Zagreb, Croatia
}

\begin{abstract}
In the literature, financial literacy and financial awareness are described as knowledge, skills and behavior that can eliminate undesirable financial risks, as well as encourage entrepreneurial behavior. Official education of citizens around the world has begun in 2003, but in Croatia such systematic approach started in 2015. Considering the fact that young people are the bearers of future trends this research focuses on identifying young people's awareness on financial issues as a precondition for financial literacy. This research was conducted using mixed methodology and Sequential Explanatory Design. The first part of the research was conducted using a survey method among 1731 students in Croatia and the second part by using focus groups that included 21 participants.
\end{abstract}

Keywords

financial literacy; media consumption; financial awareness; mixed methodology 